\title{
Anticancer activities of the ruthenium carboxylato, amido and pyridine complexes
}

\author{
RADHEY S. SRIVASTAVA ${ }^{1}$, FRANK R. FRONCZEK ${ }^{2}$, RICHARD S. PERKINS ${ }^{1}$, \\ TOMOFUSA FUKUYAMA ${ }^{3}$ and WU XU ${ }^{1}$
}

\begin{abstract}
${ }^{1}$ Department of Chemistry, University of Louisiana at Lafayette, LA 70504, USA; ${ }^{2}$ Department of Chemistry, Louisiana State University, Baton Rouge, LA 70803, USA; ${ }^{3}$ Department of Clinical Laboratory, Department of Infection Control and Prevention Kyoto University Hospital, 54 Shogoin-Kawaharacho, Sakyo-ku, Kyoto, 606-8507, Japan
\end{abstract}

Received January 19, 2010; Accepted March 17, 2010

\section{DOI: 10.3892/ijo_00000646}

\begin{abstract}
Ruthenium complexes [1-3] with oxalato, amido and pyridine ligands have been synthesized and characterized. Biological tests showed that the ruthenium complexes 2 and 3 have modest cytotoxicity on both murine cell line NIH3T3 and human cancer colon cell lines HCT116 and HT29 while complex 1 has no obvious growth defect. We further tested why complexes 2 and 3 exhibit modest cytotoxicity. Gel electrophoresis analysis demonstrates that complex 3 has the ability to cleave double-stranded DNAs in a dose-dependent manner. In contrast, complex 2 does not have detectable DNA cleavage activity. Additionally, real-time PCR analysis suggests that the observed cell growth inhibition or death could be due to the altered gene expression in the processes of cell cycle and apoptosis/necrosis caused by the addition of complexes 2 and 3. Furthermore, cell death by DNA fragmentation assay indicates that the addition of these two complexes may cause cell necrosis rather than apoptosis.
\end{abstract}

\section{Introduction}

The discovery of antitumor activity of cisplatin and other platinum derivatives has been evaluated by both in vitro cellbased assays and in vivo animal models (1-8). Following the discovery of cisplatin and cisplatin derivatives, there have been tremendous efforts aimed at investigating anticancer activity of metal-based complexes to reduce toxic sideeffects and increase drug specificity and activity. Over the years, much attention has been focused on developing cisplatin

Correspondence to: Dr Radhey S. Srivastava or Dr Wu Xu, Department of Chemistry, University of Louisiana at Lafayette, LA 70504, USA

E-mail: rss1805@louisiana.edu

E-mail: wxx6941@louisiana.edu

Key words: ruthenium complexes, X-ray, electrochemistry, anticancer, DNA binding analogues. Currently, cisplatin, carboplatin and oxaplatin are widely used anticancer drugs, and are especially effective against testicular and ovarian carcinomas, bladder tumors and tumors of the head and neck (9). It is generally believed that the ultimate target of this type of drug is DNA (10). The DNA adducts formed interfere with DNA transcription and replication, eventually leading to cell death (11). Cisplatin is relatively unreactive in high-chloride media (e.g., blood plasma) and is activated by hydrolysis of near DNA in the nucleus. In contrast, carboplatin and oxaplatin are relatively inert to hydrolysis, have a milder spectrum of side-effects and probably attack DNA by means of chelate ring-opening reactions (12). Platinum-derived drugs have massive impact on current cancer therapy, however, patients suffer from a wide range of side-effects (13). Additionally, platinumderived drugs are often limited to the types of cancer that are treated due to drug resistance $(14,15)$.

To achieve anticancer activity in a broader range of tumors and/or overcome the problems associated with platinumderived drugs, novel non-platinum and in particular ruthenium complexes with potential antitumor activity are being developed $(15,16)$. Ruthenium organometallic complexes have a spectrum of activity, suggesting that they might not share cross-resistance mechanisms with cisplatin although the primary cytotoxic lesion remains to be identified (17-21). Clearly, ruthenium complexes represent a new class of compounds endowed with antitumor activity $(1,22)$. Two ruthenium complexes NAMI-A and KP1019 are already in clinical trials (23-27). Ruthenium complexes are rich in chemistry and the side-effects of the ruthenium complexes are low compared to platinum-derived drugs because of the selective activation to cytotoxic species in solid tumor tissues (28). Ruthenium complexes display relatively low ligand exchange rates in comparison to platinum complexes (29). Slow ligand exchanges ensure that a drug reaches its biological target without prior modification. In addition, the various oxidation states (II, III and IV) of ruthenium are all accessible under physiological conditions (29). In these complexes, the ruthenium center is primarily hexacoordinated with octahedral geometry in contrast to square planar geometry of platinum (II) (30). The octahedral geometry of ruthenium complexes imposes not only different steric 
effects upon interaction with biomolecules, which in turn may cause a different anticancer profile from cisplatin, but also various other different properties (31).

We report herein synthesis and characterization of the ruthenium complexes with ligands of oxalato, amido and pyridine. We found that two ruthenium complexes with either amido or pyridine ligand showed modest anticancer activity.

\section{Materials and methods}

Synthesis of $\mathrm{K}\left[\mathrm{RuCl}(\mathrm{TMSO})_{3}\left(\eta^{2}\right.\right.$-ox $\left.)\right]$, the ruthenium complex 1 . The solvents employed in this study were reagent grade and dried over $4 \AA$ molecular sieves. All other reagents used in synthesizing the ruthenium complexes were of analytical grade. Pyridine was distilled before use. Solid potassium oxalate $(0.041 \mathrm{~g}, 0.202 \mathrm{mmol})$ was added to the solution of cis-[RuCl$\left.{ }_{2}(\mathrm{TMSO})_{4}\right](0.116 \mathrm{~g}, 0.197 \mathrm{mmol})$ dissolved in $12.0 \mathrm{ml}$ methanol. The resulting solution was refluxed for $5 \mathrm{~h}$. Solvent was removed and vacuum dried. A sticky yellow solid was obtained. On trituration with a mixture of acetone and diethylether yielded a yellow solid. The yield was $0.088 \mathrm{~g}$ $(43.6 \%)$. Elemental analysis in this study was performed by Atlantic Microlab, (Norcross, GA). Analysis calculated for $\mathrm{C}_{14} \mathrm{H}_{24} \mathrm{ClKO}_{7} \mathrm{RuS}_{3}(\mathrm{MM}=576.2, \%)$ : C, 29.18; H, 4.2. Found: C, 29.08; H, 3.96. Selected IR absorption bands in $\mathrm{KBr}\left(\mathrm{cm}^{-1}\right): v_{\text {asymm }}(\mathrm{COO}) 1669$ (vs); $v_{\text {symm }}(\mathrm{COO}) 1380$ (m); $v_{\mathrm{SO}} 1109(\mathrm{~s}) ; v_{\mathrm{Ru}-\mathrm{S}} 429(\mathrm{~m})$. The IR spectra were measured on a JASCO 480 Plus spectrophotometer with samples in compressed $\mathrm{KBr}$ discs. UV-visible spectrum obtained on a JASCO V-550 spectrophotometer in acetone: $\left(\lambda_{\max }, \mathrm{nm}\right.$ $\left(\varepsilon, \mathrm{mol}^{-1} \mathrm{~cm}^{-1}\right): 291 \mathrm{sh}(1610), 345 \mathrm{sh}(580)$.

Synthesis of trans-[RuCl$l_{2}\left(\mathrm{H}_{2} b p b\right]$, the ruthenium complex 2 . A solid sample of $0.110 \mathrm{~g}(0.340 \mathrm{mmol})$ of N,N'-bis(2pyridinecarboxamide) 1,2 , benzene $\left(\mathrm{H}_{2} \mathrm{bpb}\right)$ was added to the solution of $m e r-\left[\mathrm{RuCl}_{3}(\mathrm{TMSO})_{3}\right] 0.170 \mathrm{~g}(0.340 \mathrm{mmol})$ dissolved in dichloromethane $(20.0 \mathrm{ml})$ and the resulting solution was refluxed for $3 \mathrm{~h}$. Volume was reduced to $3.00 \mathrm{ml}$ and the solution was left at room temperature, which yielded a brown crystalline compound. The yield was $0.072 \mathrm{~g}(86.7 \%)$. Analysis calculated for $\mathrm{C}_{18} \mathrm{H}_{12} \mathrm{Cl}_{2} \mathrm{~N}_{4} \mathrm{O}_{2} \mathrm{Ru}(\mathrm{MM}=488.29, \%)$ : C, 44.27; H, 2.47; N, 11.52. Found: C, 44.65; H, 2.36; N, 11.6. Selected IR absorption bands in $\mathrm{KBr}\left(\mathrm{cm}^{-1}\right): v 429(\mathrm{Ru}-\mathrm{N})$. UV-visible spectrum in acetone: $\left(\lambda_{\max }, \mathrm{nm}\left(\varepsilon, \mathrm{mol}^{-1} \mathrm{~cm}^{-1}\right): 375\right.$ (5981), 312 (9901).

Electrochemical study of the trans-[RuCl$l_{2}\left(\mathrm{H}_{2} b p b\right]$, the ruthenium complex 2. Cyclic voltametry was carried out with a three electrode system comprised of a Pt counter electrode, a Pt disk working electrode, and a saturated calomel electrode (SCE) connected to the main cell compartment by a $\mathrm{KCl}$ salt bridge. Potential control was done with a BAS CV-50 W voltametric analyzer used in the cyclic voltametry mode. The supporting electrolyte was $0.100 \mathrm{M}$ tetrabutylammonium hexafluorophosphate. Argon was bubbled through the solution for at least $30 \mathrm{~min}$ prior to and during cyclic voltametry. Instrumental IR compensation was used when needed.
Synthesis and characterization of the ruthenium complex 3. mer- $\left[\mathrm{RuCl}_{3}(\mathrm{DMSO})_{2}(\mathrm{py})\right]$, the ruthenium complex 3, was prepared and characterized by literature procedures (32).

Plasmid DNA isolation and gel electrophoresis. pUC19 plasmid was introduced into DH5 $\alpha$ competent cells based on manufacturer's protocol (Invitrogen Corporation, Carlsbad, CA). A single colony was selected from LB plate and cultured in $5.0 \mathrm{ml}$ of $\mathrm{LB}$ medium at $37^{\circ} \mathrm{C}$ in a shaker at a speed of $300 \mathrm{rpm}$ for overnight. This starter cell culture was diluted 1:500 using freshly prepared LB medium and grew at $37^{\circ} \mathrm{C}$ in a shaker at a speed of $300 \mathrm{rpm}$ for 16-18 h. Cells were harvested at 4,000 rpm for $5 \mathrm{~min}$. The plasmid DNAs were purified from the cell culture using a Qiagen plasmid purification column based on manufacturer's protocol (Qiagen Inc., Valencia, CA). LB medium and plates contained $100 \mu \mathrm{g} / \mathrm{ml}$ ampicillin. The concentration of plasmid DNA was determined by the absorbance at $260 \mathrm{~nm}$ using $\mathrm{UV}-\mathrm{V}$ is spectrophotometry. Approximately $1.0 \mu \mathrm{g}$ of pUC19 plasmid DNA was incubated with the ruthenium complexes 1,2 and 3 at the specified concentrations in a total $20 \mu 1$ in a $37^{\circ} \mathrm{C}$ water bath for $2-32 \mathrm{~h}(33)$. At the end of incubation, bromophenol blue loading buffer was added. The samples were then loaded on a $1.0 \%$ agarose gel containing $\sim 2.0 \mu \mathrm{g} / \mathrm{ml}$ ethidium bromide. Gel electrophoresis was carried out at $150 \mathrm{~V}$ for $20 \mathrm{~min}$ in Tris-Borate-EDTA (TBE) buffer. Bands were visualized by UV light and photographed by a Bio-Rad gel documentation system (Bio-Rad Laboratories, Hercules, CA).

Culture of cell lines and cytotoxicity test. The human and murine cell lines were maintained in either T25 or T75 flasks containing DMEM medium supplemented with $10 \%$ fetal bovine serum, $1 \%$ glutamine, and $1 \%$ penicillin and streptomycin (Invitrogen) in the standard 3T3 protocol and grown at $37^{\circ} \mathrm{C}$ in a $5 \% \mathrm{CO}_{2}$ incubator (34). The ruthenium complexes dissolved in DMSO, filter-sterilized, were added into a growth medium using 1:1000 dilution to avoid the toxic effects of DMSO after the cells were plated for $24 \mathrm{~h}$. At the end of incubation with ruthenium complexes, cells were removed from flasks by trypsin-EDTA solution (Invitrogen). Cell viability was determined by the trypan blue staining and cell number was counted using a haemocytometer.

Total RNA extraction and $q R T-P C R$. Total RNA was isolated from the cell lines using TRIzol reagents (Invitrogen). cDNA was generated from $500 \mathrm{ng}$ total RNAs using superscript II reverse transcriptase (Invitrogen). qRT-PCR was performed on a MyiQ real-time PCR machine (Bio-Rad) using Qiagen SYBR-Green PCR master mix (Qiagen). qPCR primers were designed using Primer Express software (Applied Biosystems, Foster City, CA) and only sense primer and antisense primer from different exons were chosen for qRT-PCR analysis except the genes containing only one exon. A single product for each primer pair was further confirmed by gel and melt-curve analysis. mRNA level for each gene was normalized to glyceraldehyde 3-phosphate dehydrogenase (GAPDH).

Total genomic DNA isolation. The genomic DNA was isolated by modified earlier protocol (35). Cells were harvested by 


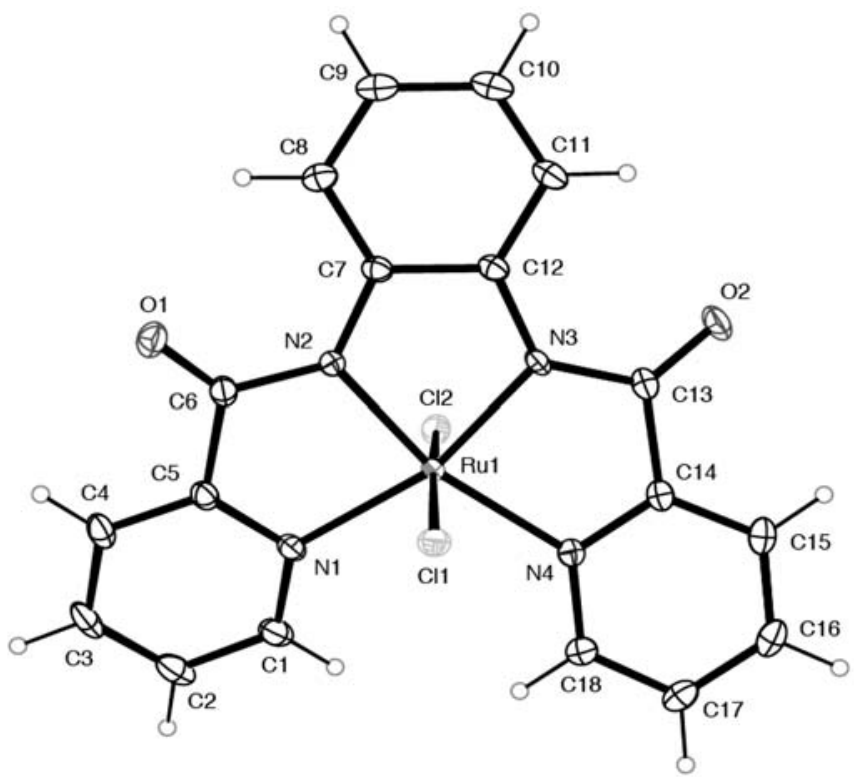

Figure 1. The molecular structure of the ruthenium complex 2, trans$\left[\mathrm{RuCl}_{2}\left(\mathrm{H}_{2} \mathrm{bpb}\right]\right.$

centrifugation at 4,000 rpm for 5 min and washed with PBS once. The cell pellets were then re-suspended in $500 \mu 1$ of lysis buffer [2.0 mM EDTA/100 mM Tris-Cl, $\mathrm{pH}$ 8.0/0.8\% (w/v) SDS] and $50 \mu \mathrm{l}$ of $10 \mathrm{mg} / \mathrm{ml}$ proteinase $\mathrm{K}$ was added. The lysate was mixed well and incubated at $37^{\circ} \mathrm{C}$ overnight. Phenol-chloroform $(300 \mu 1)(\mathrm{pH} 7.5)$ was added to the lysate and vortexed for $30 \mathrm{sec}$ twice. After centrifugation at 13,000 rpm for $10 \mathrm{~min}$, the aqueous phase was transferred into a new $1.7 \mathrm{ml}$ micro-centrifuge tube. Genomic DNA was precipitated by $1.0 \mathrm{ml}$ of isopropanol and washed once using $70 \%$ ethanol. DNA was dissolved to $10.0 \mathrm{mM}$. Tris buffer, pH 7.5 and $10.0 \mu 1$ of $10 \mathrm{mg} / \mathrm{ml}$ RNase A was added. The samples were incubated in a $37^{\circ} \mathrm{C}$ water bath for $2 \mathrm{~h}$ to remove RNA. Extracted genomic DNA solutions were applied to a $1.0 \%$ agarose gel, electrophoresed and stained by ethidium bromide.

Statistical analysis. Experimental data were subjected to computer-assisted statistical analysis of variance (ANOVA), Student's t-test and Dunnett's post test using GraphPad Prism 4.0 (GraphPad Software Inc., La Jolla, CA). Differences of $\mathrm{p}<0.05$ were considered to be significantly different from controls.

\section{Results}

The synthesis of the ruthenium complexes 1 and 2, and the $X$-ray structure of the ruthenium complex 2. A mononuclear $\mathrm{K}\left[\mathrm{RuCl}(\mathrm{TMSO})_{3}\left(\eta^{2}-\mathrm{ox}\right)\right]$, the ruthenium complex 1 , was synthesized by reacting cis-[ $\left.\mathrm{RuCl}_{2}(\mathrm{TMSO})_{4}\right]$ with 1.1 equivalent of $\mathrm{K}_{2}$ (oxalate) in refluxing methanol upon slow evaporation in a fume hood. This complex displayed an octahedral geometry. Similar results are reported by Alessio et al (36). Complex 2 was prepared by reacting $\operatorname{mer}$ - $\left[\mathrm{RuCl}_{3}(\mathrm{TMSO})_{3}\right]$ with $\mathrm{H}_{2} \mathrm{bpb}$ in refluxing dichloromethane. This complex has a distorted octahedral geometry around a ruthenium center.
Table I. The crystal data for the ruthenium complex 2.

\begin{tabular}{ll}
\hline CCDC deposit no. & $\mathrm{CCDC} 753273$ \\
Formula & $\mathrm{C}_{18} \mathrm{H}_{12} \mathrm{Cl}_{2} \mathrm{~N}_{4} \mathrm{O}_{2}$ \\
Formula weight & 488.29 \\
Crystal & Fragment, dark brown \\
Crystal size $(\mathrm{mm})$ & $0.27 \times 0.17 \times 0.15$ \\
Crystal system & monoclinic \\
Space group & $\mathrm{P} 2{ }_{1} / \mathrm{c}$ \\
$\mathrm{T}(\mathrm{K})$ & 90 \\
$\mathrm{a}(\AA)$ & $8.0020(7)$ \\
$\mathrm{b}(\AA)$ & $22.983(2)$ \\
$\mathrm{c}(\AA)$ & $9.6300(10)$ \\
$ß\left(^{\circ}\right)$ & $103.242(4)$ \\
$\mathrm{V}\left(\AA^{3}\right)$ & $1724.0(3)$ \\
$\mathrm{h}, \mathrm{k}, 1$ limits & $\pm 16,-20-22, \pm 23$ \\
$\mathrm{Z}$ & 4 \\
$\theta$ range $\left({ }^{\circ}\right)$ & $2.5-31.0$ \\
$\mu\left(\mathrm{mm}^{-1}\right)$ & 1.24 \\
Measured reflection & 34,327 \\
$\mathrm{R}\left[\mathrm{F}^{2}>2 \sigma\left(\mathrm{F}^{2}\right)\right]$ & 0.022 \\
$\mathrm{Rw}\left(\mathrm{F}^{2}\right)$ & 0.058 \\
Parameters & 245 \\
\hline & \\
\hline &
\end{tabular}

The X-ray molecular structure of 2 is shown in Fig. 1. The selected bond angles and distances are listed in Table I. The tetradentate ligand $\mathrm{H}_{2} \mathrm{bpb}$ in its deprotonated form provides two neutral pyridine nitrogen and two anionic carboxamido nitrogen donors in the equatorial plane while the axial plane is occupied by two chlorides. The geometry around ruthenium is distorted octahedral. The average $\mathrm{Ru}-\mathrm{N}_{\text {amide }}$ distance $1.9419 \AA$ is considerably shorter than the average $\mathrm{Ru}-\mathrm{N}_{\mathrm{py}}$ distance $2.0864 \AA$. The average $\mathrm{Ru}-\mathrm{Cl}$ bond length $2.355 \AA$ is comparable to the $\mathrm{Ru}-\mathrm{Cl}$ distance reported for tetradentate $\left(\mathrm{N}_{2} \mathrm{O}_{2}\right)$ ligands such as $\mathrm{H}_{2}$-salen, substituted $\mathrm{H}_{2}$-salophen and $\mathrm{H}_{2}$ bpb derivatives (Table II).

Electrochemical study of the ruthenium complex 2. Cyclic voltammetry of trans-[ $\mathrm{RuCl}_{2}\left(\mathrm{H}_{2} \mathrm{bpb}\right]$, the ruthenium complex 2, was carried out at sweep rates ranging between 100 to $3011 \mathrm{mV} / \mathrm{s}$. Fig. 2 shows the last two of five sweeps carried out at $1003 \mathrm{mV} / \mathrm{s}$. Higher sweep rates gave similar graphs. Lower sweep rates displayed signals at cathodic potentials due to further reduction and subsequent oxidation, possibly of separate ligands. The peaks in Fig. 2 are likely due to the $\mathrm{Ru}(\mathrm{III}) / \mathrm{Ru}$ (II) redox couple. The peak separation of $167 \mathrm{mV}$ indicates an irreversible process.

Effects on cell viability by the ruthenium complexes 1, 2 and 3. A number of ruthenium complexes were reported to have anti-metastatic activity (37-39). Specifically, a certain ruthenium complexes with heterocycles coordinated to ruthenium center through nitrogen have been shown to act as cytostatic and cytotoxic drugs on colorectal tumor cells both 


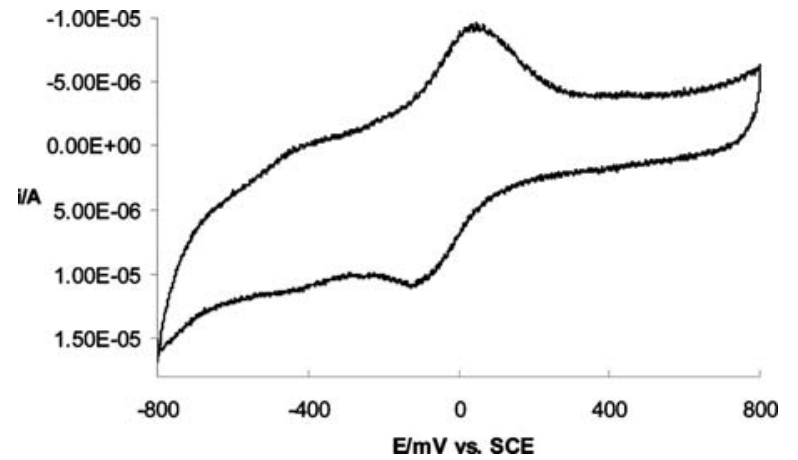

Figure 2. Cyclic voltametric curve of $1.0 \mathrm{mM}$ and $0.100 \mathrm{M} \mathrm{Bu}_{4} \mathrm{NPF}_{6}$ in acetone at a sweep rate of $1003 \mathrm{mV} / \mathrm{s}$.

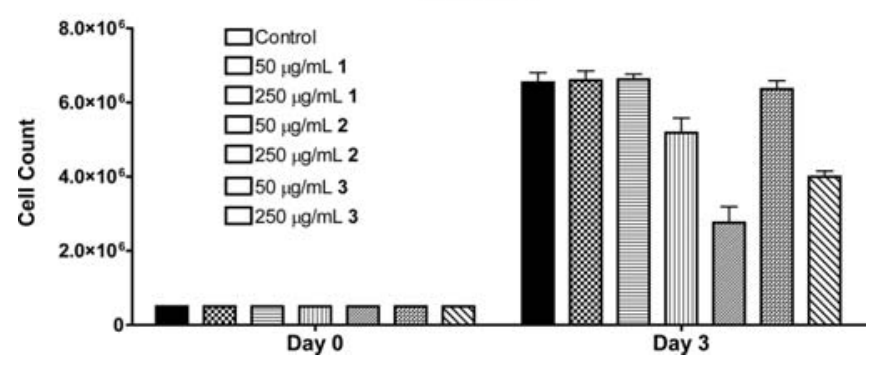

Figure 3. Effects on cell viability by the complexes 1, 2 and 3 . The murine NIH3T3 cells were incubated with varying concentrations [0 (control), 50 and $250 \mu \mathrm{g} / \mathrm{ml}]$ of complexes 1,2 and 3 .
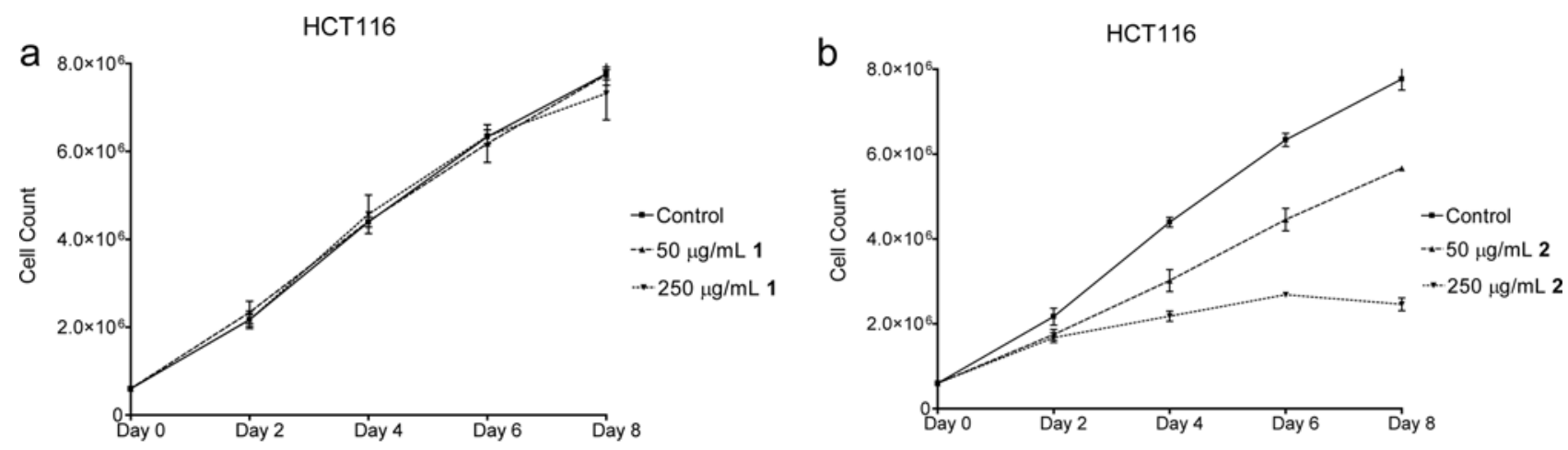

HCT116

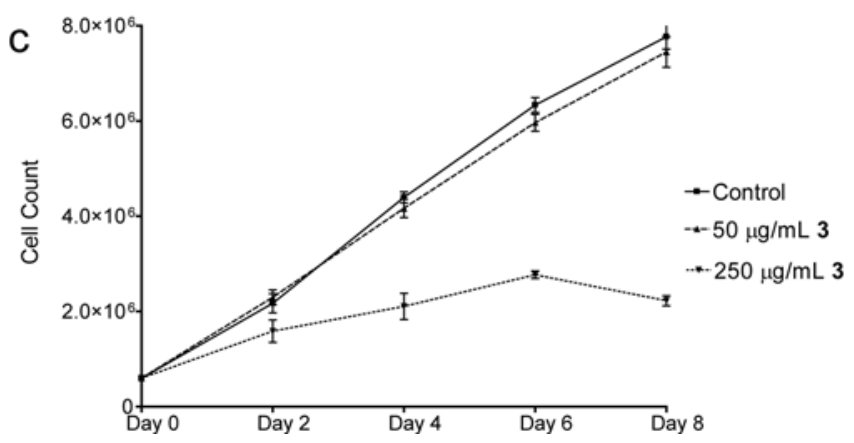

Figure 4. Effects on cell viability by the complexes 1,2 and 3. The human colon cancer HCT116 cells were incubated with varying concentrations [0 (control), 50 and $250 \mu \mathrm{g} / \mathrm{ml}$ ] of complexes 1,2 and 3 .

in vivo and in vitro (40-43). In the present work, the effects of the ruthenium complexes 1,2 and 3 with ligands of oxalato, amido and pyridine on cell growth were investigated using two human colorectal carcinoma cell lines (HCT116 and HT29). Additionally, we also investigated the cytotoxicity of these complexes using a cell model constituted by a culture derived from NIH3T3 mouse fibroblast line (NIH3T3) obtained after prolonged serum deprivation (4). Fig. 3 reports the effects of 1,2 and 3 on in vitro cultured NIH3T3 cells treated for three days at concentrations of 0,50 , or $250 \mu \mathrm{g} / \mathrm{ml}$. Our data suggest that $2(250 \mu \mathrm{g} / \mathrm{ml}=434 \mu \mathrm{M})$ and $3(250 \mu \mathrm{g} / \mathrm{ml}=565 \mu \mathrm{M})$ can inhibit NIH3T3 while 1 has no obvious cell growth defect. Our experimental results of 1 , 2 and 3 on in vitro cultured HCT116 and HT29 cells indicate that complexes 2 and 3 can inhibit the growth of two colon cancer cell lines in a dose-dependent fashion. Similar to NIH3T3 cells, complex 1 has no anticancer activity. In summary, a detectable reduced cell number was observed in NIH3T3, HCT116 (Fig. 4a-c), and HT29 (data not shown) cells caused by the addition of 2 and 3 . When the cells were grown with 2 and 3 for a longer period of time, all the cells died while the control cells were still alive. This was confirmed by trypan blue staining.

DNA binding activity by the ruthenium complexes 2 and 3 . Ruthenium complexes have been reported to have DNA binding properties (44-48). The observed cell growth inhibition of complexes 2 and 3 made us hypothesize that 2 and 3 might have the property of either DNA binding, or cross-linking, or cleavage. Agarose gel electrophoresis was 
a

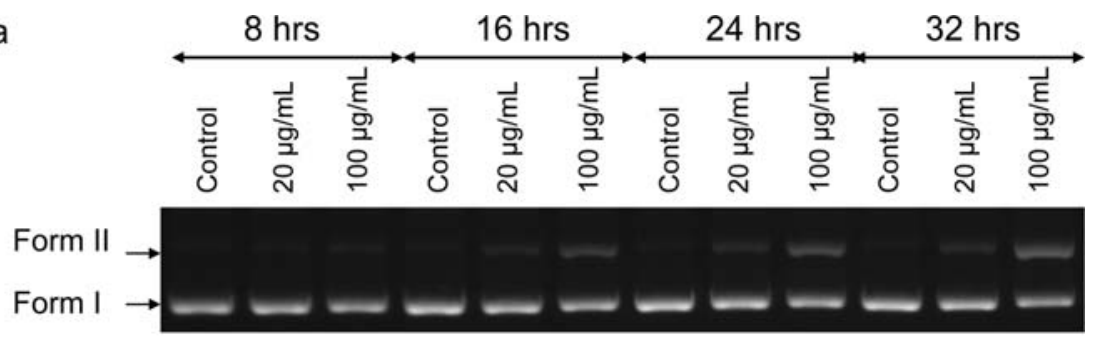

b

Complex 3

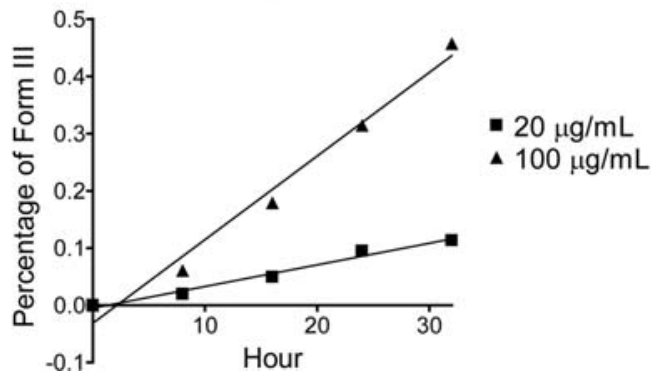

Figure 5. Cleavage profile of pUC19 plasmid DNA by complex 3. (a) Plasmid DNA (1.0 $\mu \mathrm{g})$ was incubated with varying concentrations of 3 in 1.0 mM Tris-Cl buffer, $\mathrm{pH} 7.0$ at $37^{\circ} \mathrm{C}$. (b) The data were fit well with linear regression using Prism 4.0.

Table II. The selected bond lengths $(\AA)$ and bond angles $\left(^{\circ}\right)$ for the ruthenium complex 2 .

\begin{tabular}{lllr}
\hline \multicolumn{2}{c}{$\begin{array}{c}\text { Bond lengths } \\
\text { (bond angles) }\end{array}$} & \multicolumn{2}{c}{$\begin{array}{c}\text { Bond lengths } \\
\text { (bond angles) }\end{array}$} \\
\hline Ru1-N1 & $2.0929(12)$ & N2-Ru1-N4 & $163.69(5)$ \\
Ru1-N4 & $2.0799(12)$ & N2-Ru1-N3 & $82.52(5)$ \\
Ru1-N2 & $1.9337(12)$ & N3-Ru1-N4 & $81.62(7)$ \\
Ru1-N3 & $1.9501(11)$ & N2-Ru1-N1 & $81.27(5)$ \\
Ru1-Cl2 & $2.3524(4)$ & N3-Ru1-N1 & $163.34(5)$ \\
Ru1-Cl1 & $2.3576(4)$ & N4-Ru1-N1 & $114.78(5)$ \\
\hline
\end{tabular}

used to identify the possible interactions of 2 and 3 with plasmid DNA. A plasmid pUC19 with 2,686 base-pairs in length and with a high copy number was chosen in this study. pUC19 is a commonly used plasmid cloning vector, which carries a 54 base-pair multiple cloning site polylinker that contains unique sites for 13 different hexanucleotide-specific restriction endonucleases. It can be easily linearized by any of these restriction endonucleases. Plasmid DNA naturally exists as a supercoiled molecule, which is often called form I. The majority of purified plasmid DNA in a laboratory is a covalently closed supercoiled molecule. If one or more phosphate bonds anywhere in the backbone of supercoiled DNA are broken, the molecule unravels to a relaxed open circular DNA (form II). The linear plasmid DNA, which is called form III, can be generated if the phosphodiester bonds of both strands are broken at the same place. Different forms of the same plasmid can be identified by agarose gel electrophoresis since they will migrate at different positions in the agarose gel. If complexes 2 and 3 can interact with the double-stranded DNA, we expect to identify the altered migration patterns of any forms in agarose gel. Gel electrophoresis clearly demonstrated that complex 3 can interact with plasmid DNA in a dose-dependent manner since form I was converted to form II (Fig. 5). In contrast, complex 2 does not have DNA binding properties (data not shown). It has been demonstrated that ruthenium complexes can crosslink to the linear DNA since linear DNA has phosphate and hydroxyl ends. In order to test this possibility, pUC19 DNA was linearized by EcoRI and incubated with complexes 2 and 3 . The results show there are no obvious altered migration patterns. Complex 1 does not have a DNA binding property (data not show).

Gene expression of the ruthenium complexes 2 and 3 in NIH3T3. Our experimental data suggest that complexes 2 and 3 can inhibit the growth of HCT116, HT-29 and NIH 3T3. We further investigated the molecular mechanism of this cell growth inhibited by these two complexes by testing gene expression in the process of cell death and cycle using realtime RT-qPCR, which measures mRNA from NIH3T3 cells following 18-h treatment with $174 \mu \mathrm{M}$ complex 2 and $226 \mu \mathrm{M} 3$. Test gene expression was normalized to GAPDH mRNA. Tumor suppressor gene p53 is implicated in the response of cancer cells to many cytotoxic agents $(49,50)$. It was reported that several ruthenium-derived complexes led to G1 arrest and induced apoptosis in tumor cell lines derived from glioblastomas, neuroblastomas and lymphoid tumors at least as efficiently as cisplatin because both rutheniumderived complexes and cisplatin-induced p53-dependent and p53-independent apoptosis $(1,22)$. Two p53 target genes, p21/WAF1 ( $C d k n l a)$ and PUMA (Bbc3), linked to cell growth arrest and apoptosis, were selected to test if 2 and 3 can induce p53-dependent apoptosis. We observed that p21/WAF1 was approximately four-fold up-regulated in 2 and two-fold up-regulated in 3 while there were no obvious differences for PUMA gene expression in these two com- 
a

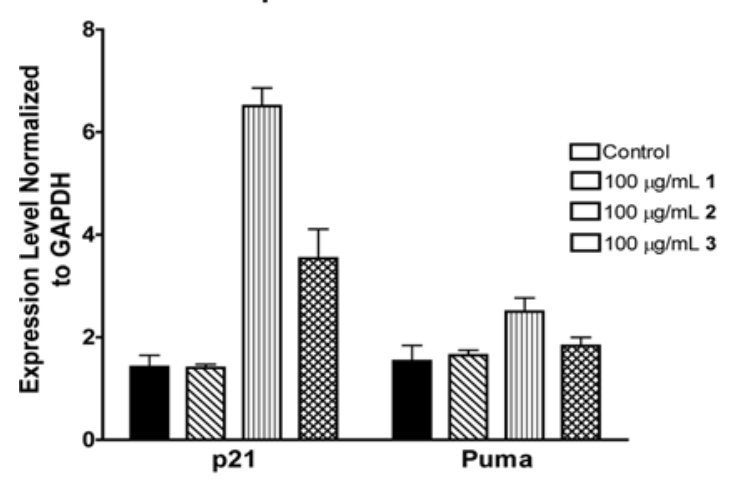

C

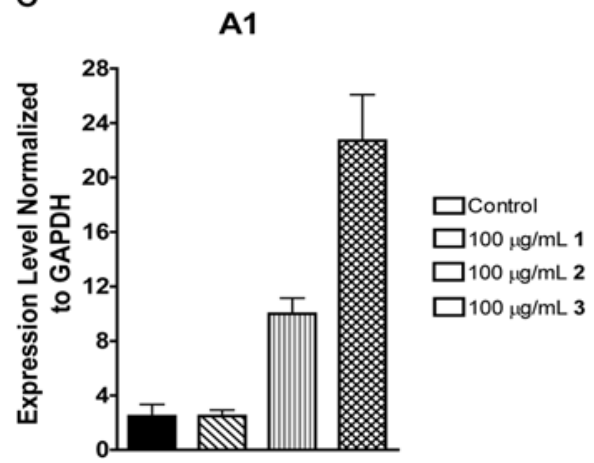

b

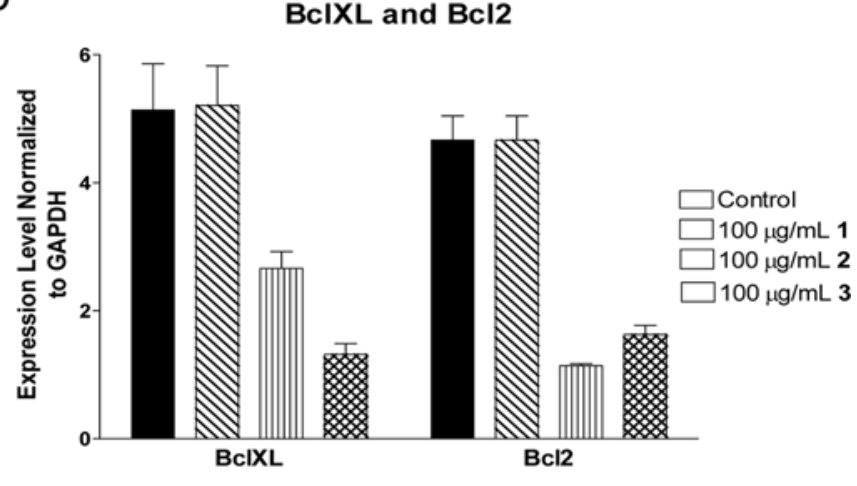

d

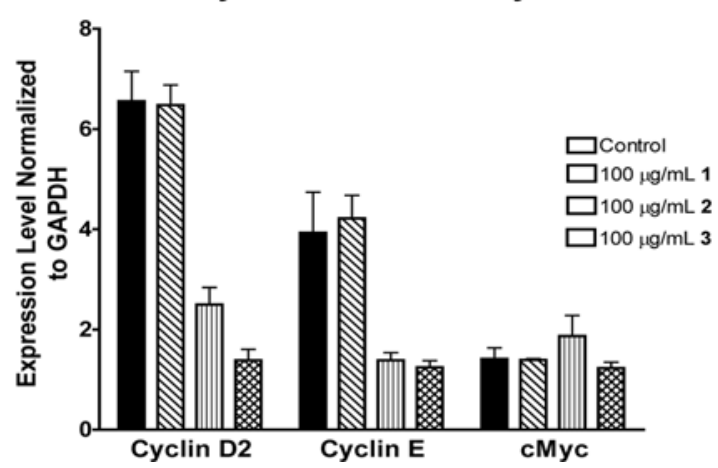

Figure 6. Gene expression of the ruthenium complexes in NIH3T3. Gene expression in the process of cell death and cycle was investigated using real-time RT-qPCR, which measures mRNA from NIH3T3 cells following 18-h treatment with $148 \mu \mathrm{M}$ complex $1,174 \mu \mathrm{M}$ complex 2 and $226 \mu \mathrm{M}$ complex 3.

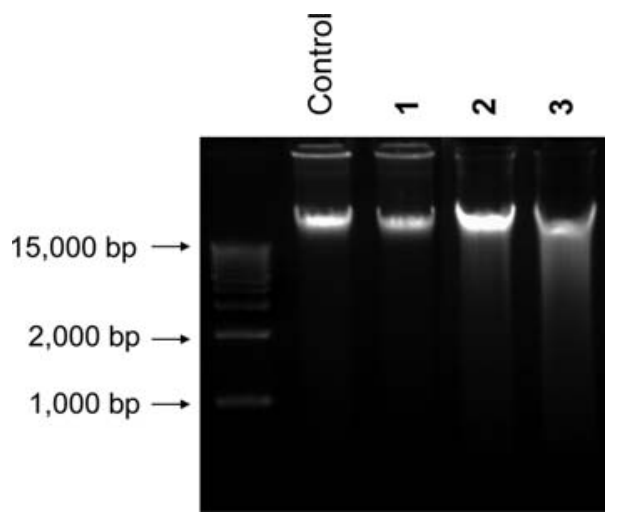

Figure 7. Partial DNA smear was observed in the NIH3T3 cells treated by the ruthenium complexes 1,2 and 3 . NIH3T3 cells were treated with $100 \mu \mathrm{g} / \mathrm{ml}$ complexes 1, 2 and 3 for $24 \mathrm{~h}$. NIH3T3 cells treated with same volume of DMSO used in the ruthenium complexes for $24 \mathrm{~h}$ serves as a control.

plexes (Fig. 6a). The ratio of pro- to anti-apoptotic genes has been reported to determine the threshold for the induction of mitochondrial-dependent apoptosis. Two anti-apoptotic genes Bcl-XL (Bcl2ll) and Bcl-2 showed two- to three-fold down-regulation by 2 and 3 (Fig. 6b). It is interesting that another anti-apoptotic gene A1 (Ala,Bfl-1,Bcl2ala) was three- to six-fold up-regulated in the treated cells by complexes 2 and 3 (Fig. 6c). Ru complexes have been reported to exhibit potential for apoptosis induction and caused cell cycle arrest in the $\mathrm{S}$ phase as well as a decrease of the G1 and G2 percent of cancer cells (51-56). Two cell cycle-related genes cyclin D2 (Ccnd2) and cyclin E1 (Ccnel) showed approximately two- to three-fold down-regulation in complexes 2 and 3. cMyc plays an essential role in regulating cell cycle $(57,58)$. We did not observe an obvious difference for cMyc gene expression in the cells treated with 2 and 3 (Fig. 6d). The gene expression in $148 \mu \mathrm{M}$ complex 1 is nearly the same as the control for all the tested genes.

Cell death by DNA fragmentation assay. Cell death may occur by two mechanisms: apoptosis and necrosis. During apoptosis, cellular endonucleases cleave nuclear DNA between nucleosomes, producing a mix of DNA fragments whose length varies in multiples of 180-200 bp. A ladder pattern in agarose gel is the key feature of apoptotic cells. On the other hand, the genomic DNA from necrotic cells has a random and general cleavage pattern. A genomic DNA smear is the key feature of necrotic cells. The RT-qPCR data suggest that the cells treated with $174 \mu \mathrm{M}$ complex 2 and $226 \mu \mathrm{M}$ complex 3 underwent the altered transcription programs. In order to distinguish the mechanisms of cell death caused by 2 and 3, we performed genomic DNA fragment assay. Partial DNA smear, rather than DNA ladder, was observed in the NIH3T3 cells treated by complexes 2 and 3 for $24 \mathrm{~h}$, suggesting that cell death caused by 2 and 3 may undergo the necrotic pathway (Fig. 7). No obvious DNA smear was observed in these complexes. 


\section{Discussion}

NAMI-A, the first ruthenium complex accomplished phase I clinical trials, belongs to the class of ruthenium dimethylsulfoxide complexes and shows a remarkable high efficiency against certain types of human tumors $(1,27,28,59)$. Because of the S-bonded DMSO ligand, NAMI-A is easily reduced to the corresponding ruthenium(II) species by biological reducing agents under physiological conditions (60). It has been proven that these reduced species maintain their anticancer activities. Ruthenium complexes 1 and 3 have DMSO ligands. Only complex 3 shows modest anticancer activity in our assays. It is possible that complex 3 is relatively easy to reduce compared to complex 1 although it needs further to be experimentally investigated. Both complexes 2 and 3 have similar anticancer activity. However, complex 3 has DNA binding activity while complex 2 does not. It has been reported that anticancer activity of ruthenium complexes appears not to be always related to their DNA binding activity (61). Instead, some ruthenium complexes can interact with proteins. For example, NAMI-A interferes with fibrous collagen of the lung and with basement membrane collagen type IV. It significantly increases the thickness of connective tissue around the tumor capsule and around tumor blood vessels, thereby probably hindering blood flow to the tumor $(1,21)$.

\section{Supplementary material}

Complete crystallographic data tables for ruthenium complex 2 have been deposited with Cambridge Crystallographic Database in CIF format. Copies of this information may be obtained free of charge from the Director, CCDC, 12 Union Road, Cambridge, CB21EZ, UK (Fax: +44-1223-336-033, email: deposit@ccdc.cam.ac.uk, http://www.ccdc.cam.ac.uk). CCDC deposit number is CCDC 753273.

\section{Acknowledgements}

Financial support provided by the Louisiana Board of Regents Support Fund (to RSS) is greatly appreciated. The purchase of the diffractometer was made possible by Grant no. LEQSF(1999-2000)-ESH-TR-13, administered by the Louisiana Board of Regents. W.X. thanks the start-up funds from the University of Louisiana at Lafayette. L.E. Cole and M.D. Abascal, two undergraduate students from the Department of Biology, University of Louisiana at Lafayette participated in this work.

\section{References}

1. Alessio E, Mestroni G, Bergamo A and Sava G: Ruthenium anticancer drugs. Metal Ions Biol Syst 42: 323-351, 2004.

2. Rosenberg B, Vancamp L and Krigas T: Inhibition of cell division in Escherichia Coli by electrolysis products from a platinum electrode. Nature 205: 698-699, 1965.

3. Rosenberg B, VanCamp L, Trosko JE and Mansour VH: Platinum compounds: a new class of potent antitumour agents. Nature 222: 385-386, 1969

4. Spano A, Monaco G, Barni S and Sciola L: Cisplatin treatment of NIH/3T3 cultures induces a form of autophagic death in polyploid cells. Histol Histopathol 23: 717-730, 2008.
5. Yang C, Kaushal V, Haun RS, Seth R, Shah SV and Kaushal GP: Transcriptional activation of caspase- 6 and -7 genes by cisplatininduced p53 and its functional significance in cisplatin nephrotoxicity. Cell Death Differ 15: 530-544, 2008.

6. Pabla N, Huang S, Mi QS, Daniel R and Dong Z: ATR-Chk2 signaling in p53 activation and DNA damage response during cisplatin-induced apoptosis. J Biol Chem 283: 6572-6583, 2008.

7. Wang D and Lippard SJ: Cellular processing of platinum anticancer drugs. Nat Rev Drug Discov 4: 307-320, 2005.

8. Rixe O, Ortuzar W, Alvarez M, et al: Oxaliplatin, tetraplatin, cisplatin, and carboplatin: spectrum of activity in drug-resistant cell lines and in the cell lines of the National Cancer Institute's Anticancer Drug Screen panel. Biochem Pharmacol 52: 1855-1865, 1996.

9. Basu Baul T and de Vos D: In vitro cytotoxic evaluation of novel dichlorodiorgano[N-(2-pyridylmethylene)arylamine] tin(IV) derivatives in human tumor cell lines. Invest New Drugs (In press).

10. Reedijk J: Why does cisplatin reach guanine-n7 with competing s-donor ligands available in the cell? Chem Rev 99: 2499-2510, 1999.

11. Jamieson ER and Lippard SJ: Structure, recognition, and processing of cisplatin-DNA adducts. Chem Rev 99: 2467-2498, 1999.

12. Wang F, Habtemariam A, van der Geer EP, et al: Controlling ligand substitution reactions of organometallic complexes: tuning cancer cell cytotoxicity. Proc Natl Acad Sci USA 102: 18269-18274, 2005.

13. Jakupec MA, Galanski M and Keppler BK: Tumour-inhibiting platinum complexes-state of the art and future perspectives. Rev Physiol Biochem Pharmacol 146: 1-54, 2003.

14. Boerner LJ and Zaleski JM: Metal complex-DNA interactions: from transcription inhibition to photoactivated cleavage. Curr Opin Chem Biol 9: 135-144, 2005.

15. Ott I and Gust R: Non-platinum metal complexes as anti-cancer drugs. Archiv der Pharmazie 340: 117-126, 2007.

16. Keppler BK, Berger MR and Heim ME: New tumor-inhibiting metal complexes. Cancer Treat Rev 17: 261-277, 1990.

17. Chen H, Parkinson JA, Parsons S, Coxall RA, Gould RO and Sadler PJ: Organometallic ruthenium(II) diamine anticancer complexes: arene-nucleobase stacking and stereospecific hydrogen-bonding in guanine adducts. J Am Chem Soc 124: 3064-3082, 2002.

18. Morris RE, Aird RE, Murdoch Pdel S, et al: Inhibition of cancer cell growth by ruthenium(II) arene complexes. J Med Chem 44: 3616-3621, 2001.

19. Novakova O, Chen H, Vrana O, Rodger A, Sadler PJ and Brabec V: DNA interactions of monofunctional organometallic ruthenium(II) antitumor complexes in cell-free media. Biochemistry 42: 11544-11554, 2003.

20. Chen H, Parkinson JA, Morris RE and Sadler PJ: Highly selective binding of organometallic ruthenium ethylenediamine complexes to nucleic acids: novel recognition mechanisms. J Am Chem Soc 125: 173-186, 2003.

21. Aird RE, Cummings J, Ritchie AA, et al: In vitro and in vivo activity and cross resistance profiles of novel ruthenium (II) organometallic arene complexes in human ovarian cancer. Br J Cancer 86: 1652-1657, 2002.

22. Alessio E, Mestroni G, Bergamo A and Sava G: Ruthenium antimetastatic agents. Curr Top Med Chem 4: 1525-1535, 2004.

23. Alessio E, Balducci G, Calligaris M, Costa G, Attia WM and Mestroni G: Synthesis, molecular structure, and chemical behavior of hydrogen trans-bis(dimethyl sulfoxide)tetrachlororuthenate(III) and mer-trichlorotris(dimethyl sulfoxide) ruthenium(III): the first fully characterized chloride-dimethyl sulfoxide-ruthenium(III) complexes. Inorg Chem 30: 609-618, 2002.

24. Lentz F, Drescher A, Lindauer A, Henke M, Hilger RA, Hartinger CG, Scheulen ME, Dittrich C, Keppler BK and Jaehde U: Pharmacokinetics of a novel anticancer ruthenium complex (KP1019, FFC14A) in a phase I dose-escalation study. pp97-103,110.1097/CAD. 1090b1013e328322fbc328325, 2009.

25. Heffeter P, Pongratz M, Steiner E, et al: Intrinsic and acquired forms of resistance against the anticancer ruthenium compound KP1019 [Indazolium trans-[tetrachlorobis $(1 \mathrm{H}$-indazole) ruthenate (III)] (FFC14A). J Pharmacol Exp Ther 312: 281-289, 2005.

26. Hartinger CG, Jakupec MA, Zorbas-Seifried S, et al: KP1019, a new redox-active anticancer agent - preclinical development and results of a clinical phase I study in tumor patients. Chem Biodivers 5: 2140-2155, 2008. 
27. Rademaker-Lakhai JM, van den Bongard D, Pluim D, Beijnen JH and Schellens JH: A Phase I and pharmacological study with imidazolium-trans-DMSO-imidazole-tetrachlororuthenate, a novel ruthenium anticancer agent. Clin Cancer Res 10: 3717-3727, 2004.

28. Bergamo A, Gagliardi R, Scarcia V, et al: In vitro cell cycle arrest, in vivo action on solid metastasizing tumors, and host toxicity of the antimetastatic drug NAMI-A and cisplatin. J Pharmacol Exp Ther 289: 559-564, 1999.

29. Page SM, Boss SR and Barker PD: Tuning heavy metal compounds for anti-tumor activity: is diversity the key to ruthenium's success? Future Med Chem 1: 541-559, 2009.

30. Clarke MJ: Ruthenium metallopharmaceuticals. Coord Chem Rev 236: 209-233, 2003.

31. Geremia S, Alessio E and Todone F: Synthesis and crystal structure of new Ru(III)-sulfoxide complexes containing a planar N-ligand: mer,cis-RuCl3(1Me-Im)2(S-DMSO) and [4Et$\mathrm{PyH}][$ trans-RuCl4(4Et-Py)(S-DMSO)]. Inorganica Chim Acta 253: 87-90, 1996.

32. Chaudhuri UP, Powell DR and Houser RP: New examples of [mu]-[eta]2:[eta]2-disulfido dicopper(II,II) complexes with bis(tetramethylguanidine) ligands. Inorganica Chim Acta 362 2371-2378, 2009.

33. Xu W, Loukaa FR, Doulaina PE, Landry CA, Mautner FA and Massoud SS: Hydrolytic cleavage of DNA promoted by cobalt(III)-tetraamine complexes: Synthesis and characterization of carbonatobis[2-(2-pyridylethyl)]-(2-pyridylmethyl) aminecobalt(III) perchlorate. Polyhedron 28: 1221-1228, 2009.

34. Xu W, Kasper LH, Lerach S, Jeevan T and Brindle PK: Individual CREB-target genes dictate usage of distinct cAMP-responsive coactivation mechanisms. EMBO J 26: 2890-2903, 2007.

35. McGahon AJ, Martin SJ, Bissonnette RP, et al: The end of the (cell) line: methods for the study of apoptosis in vitro. Methods Cell Biol 46: 153-185, 1995.

36. Bratsos I, Zangrando E, Serli B, Katsaros N and Alessio E: The unprecedented bridging coordination mode of 1,1-cyclobutane dicarboxylate ([micro sign]-cbdc-O,O[prime or minute]) stabilized by intramolecular hydrogen bonds in ruthenium(ii) complexes. Dalton Trans 21: 3881-3885, 2005.

37. Deshpande MS, Kumbhar AA and Kumbhar AS: Hydrolytic cleavage of DNA by a ruthenium(II) polypyridyl complex. Inorg Chem 46: 5450-5452, 2007.

38. Jackson BA and Barton JK: Probing nucleic acid structure with shape-selective rhodium and ruthenium complexes. Current Protocols in Nucleic Acid Chemistry. Edited by Serge L. Beaucage ... et al, Chapter 6: Unit 6, 2, 2001.

39. Tan LF, Wang F, Chao H, Zhou YF and Weng C: Ruthenium(II) mixed-ligand complex containing 2-(4'benzyloxy-phenyl)imidazo[4,5-f] $[1,10]$ phenanthroline: synthesis, DNA-binding and photocleavage studies. J Inorg Biochem 101: 700-708, 2007

40. Kapitza S, Jakupec MA, Uhl M, Keppler BK and Marian B: The heterocyclic ruthenium(III) complex KP1019 (FFC14A) causes DNA damage and oxidative stress in colorectal tumor cells. Cancer Lett 226: 115-121, 2005.

41. Sava G and Bergamo A: Ruthenium-based compounds and tumour growth control (review). Int J Oncol 17: 353-365, 2000.

42. Berger MR, Garzon FT, Keppler BK and Schmahl D: Efficacy of new ruthenium complexes against chemically induced autochthonous colorectal carcinoma in rats. Anticancer Res 9: 761-765, 1989.

43. Seelig MH, Berger MR and Keppler BK: Antineoplastic activity of three ruthenium derivatives against chemically induced colorectal carcinoma in rats. J Cancer Res Clin Oncol 118: 195-200, 1992.

44. Nagababu P, Latha JN and Satyanarayana S: DNA-binding studies of mixed-ligand (ethylenediamine)ruthenium(II) complexes. Chem Biodivers 3: 1219-1229, 2006.
45. Otero L, Smircich P, Vieites M, et al: DNA conformational changes and cleavage by ruthenium(II) nitrofurylsemicarbazone complexes. J Inorg Biochem 101: 74-79, 2007.

46. Lin X, Ramamurthi K, Mishima M, Kondo A, Christen RD and Howell SB: P53 modulates the effect of loss of DNA mismatch repair on the sensitivity of human colon cancer cells to the cytotoxic and mutagenic effects of cisplatin. Cancer Res 61: 1508-1516, 2001.

47. Izbicka E, Davidson K, Lawrence R, Cote R, MacDonald JR and Von Hoff DD: Cytotoxic effects of MGI 114 are independent of tumor p53 or p21 expression. Anticancer Res 19: 1299-1307, 1999.

48. Gaiddon C, Jeannequin P, Bischoff P, Pfeffer M, Sirlin C and Loeffler JP: Ruthenium (II)-derived organometallic compounds induce cytostatic and cytotoxic effects on mammalian cancer cell lines through p53-dependent and p53-independent mechanisms. J Pharmacol Exp Ther 315: 1403-1411, 2005.

49. Strasberg Rieber M, Anzellotti A, Sanchez-Delgado RA and Rieber M: Tumor apoptosis induced by ruthenium(II)-ketoconazole is enhanced in nonsusceptible carcinoma by monoclonal antibody to EGF receptor. Int J Cancer 112: 376-384, 2004.

50. Arandjelovic S, Tesic Z, Perego P, et al: Cellular sensitivity to beta-diketonato complexes of ruthenium(III), chromium(III) and rhodium(III). Med Chem [Shariqah (United Arab Emirates)] 2: 227-237, 2006.

51. Sava G, Frausin F, Cocchietto M, et al: Actin-dependent tumour cell adhesion after short-term exposure to the antimetastasis ruthenium complex NAMI-A. Eur J Cancer 40: 1383-1396, 2004.

52. Bergamo A, Zorzet S, Cocchietto M, Carotenuto ME, Magnarin M and Sava G: Tumour cell uptake G2-M accumulation and cytotoxicity of NAMI-A on TS/A adenocarcinoma cells. Anticancer Res 21: 1893-1898, 2001.

53. Bergamo A, Zorzet S, Gava B, et al: Effects of NAMI-A and some related ruthenium complexes on cell viability after short exposure of tumor cells. Anticancer Drugs 11: 665-672, 2000.

54. Cheng SW, Davies KP, Yung E, Beltran RJ, Yu J and Kalpana GV: c-MYC interacts with INI1/hSNF5 and requires the SWI/SNF complex for transactivation function. Nat Genet 22: 102-105, 1999.

55. Galaktionov K, Chen X and Beach D: Cdc25 cell-cycle phosphatase as a target of c-myc. Nature 382: 511-517, 1996.

56. Leone G, DeGregori J, Sears R, Jakoi L and Nevins JR: Myc and Ras collaborate in inducing accumulation of active cyclin E/Cdk2 and E2F. Nature 387: 422-426, 1997.

57. Seoane J, Le HV and Massague J: Myc suppression of the p21(Cip1) Cdk inhibitor influences the outcome of the p53 response to DNA damage. Nature 419: 729-734, 2002.

58. Trumpp A, Refaeli Y, Oskarsson T, et al: c-Myc regulates mammalian body size by controlling cell number but not cell size. Nature 414: 768-773, 2001.

59. Sava G, Zorzet S, Turrin C, et al: Dual action of NAMI-A in inhibition of solid tumor metastasis: selective targeting of metastatic cells and binding to collagen. Clin Cancer Res 9: 1898-1905, 2003.

60. Sava G, Bergamo A, Zorzet S, et al: Influence of chemical stability on the activity of the antimetastasis ruthenium compound NAMI-A. Eur J Cancer 38: 427-435, 2002.

61. Zorzet S, Bergamo A, Cocchietto M, et al: Lack of in vitro cytotoxicity, associated to increased $\mathrm{G}(2)-\mathrm{M}$ cell fraction and inhibition of matrigel invasion, may predict In vivo-selective antimetastasis activity of ruthenium complexes. J Pharmacol Exp Ther 295: 927-933, 2000. 